\title{
Structural characterization of the fusobacterial non-specific porin FomA suggests a 14- stranded topology, unlike the classical porins
}

\author{
Pål Puntervoll, Morten Ruud, Live J. Bruseth, Hans Kleivdal, \\ Bente T. Høgh, Roland Benz† and Harald B. Jensen
}

\begin{abstract}
Author for correspondence: Pål Puntervoll. Tel: +47 55584500. Fax: +4755589683. e-mail:pal.puntervoll@mbi.uib.no
\end{abstract}

Department of Molecular Biology, University of Bergen, $\mathrm{HiB}$,

Thormøhlensgate 55, N-5020 Bergen, Norway

\begin{abstract}
Native and recombinant FomA proteins were extracted by detergent from the cell envelopes of Fusobacterium nucleatum and Escherichia coli, and purified to near homogeneity by chromatography. Circular dichroism analysis revealed that the FomA protein consists predominantly of $\beta$-sheets, in line with the previously proposed 16-stranded $\beta$-barrel topology model. Results obtained by trypsin treatment of intact cells and cell envelopes of $F$. nucleatum, and from limited proteolysis of purified FomA protein, indicated that the $\mathbf{N}$-terminal part of the FomA protein is not an integral part of the $\beta$-barrel, but forms a periplasmic domain. Based on these results a new topology model is proposed for the FomA protein, where the C-terminal part forms a 14-stranded $\beta$-barrel separate from the periplasmic $\mathbf{N}$-terminal domain.
\end{abstract}

Keywords: Fusobacterium nucleatum, porins, outer-membrane proteins, circular dichroism

\section{INTRODUCTION}

Porins from several Gram-negative bacteria have been studied to variable extents over the last two decades. However, the majority of studies have been performed on porins from proteobacterial species. These studies have shown that porins are outer-membrane proteins (OMPs) that allow non-specific diffusion of solutes usually smaller than $650 \mathrm{Da}$ (Nakae, 1976). The structures of several proteobacterial porins have been resolved, revealing that they exist as trimers, where each monomer forms a separate channel across the outer membrane (OM) (Cowan et al., 1992; Dutzler et al., 1999; Hirsch et al., 1997; Kreusch \& Schulz, 1994; Weiss \& Schulz, 1992; Zeth et al., 2000). Three of the four proteobacterial subgroups now have at least one solved porin structure, and despite substantial sequence variability, the structures show remarkably similar features. The monomer consists of 16 transmembrane antiparallel $\beta$-strands that hydrogen bond to form a $\beta$-barrel. The $\beta$ -

\footnotetext{
† Present address: Lehrstuhl für Biotechnologie, Theodor-Boveri-Institut (Biozentrum) der Universität Würzburg, Germany.

Abbreviations: $C D$, circular dichroism; FomA, fusobacterial outer-membrane protein $\mathrm{A}$; OBG, octyl $\beta$-glucopyranoside; OM, outer membrane; OMP, outer-membrane protein.
}

strands are connected by turns or short loops at the periplasmic side, and longer loops exposed to the outside. In general, hydrophobic residues face the lipids and the trimer interface, whereas hydrophilic residues face the channel, thus allowing the channel to be waterfilled. Due to the stability of the $\beta$-barrel structure, most $\beta$-barrel proteins, including the porins, are resistant to denaturation by SDS at lower temperatures (Heller, 1978; Koebnik et al., 2000). This property is termed heat modifiability, since the compactly folded native proteins migrate differently in SDS-PAGE compared to the denatured proteins. Also common to all porins with resolved structure is that the third surface-exposed loop actually folds back into the pore lumen, where it constricts the pore and plays a major role in determining the permeability properties of the porin (Cowan, 1993).

The Gram-negative anaerobe Fusobacterium nucleatum is an oral bacterium that exists as a part of the normal oral microflora (Bolstad et al., 1996). It has a pathogenic potential and is implicated in periodontal diseases as well as being the most common periodontal bacterium in clinical infections of other body sites (Moore \& Moore, 1994). The major OMP of F. nucleatum, FomA, has been shown to function as a non-specific porin in lipid bilayer membranes (Kleivdal et al., 1995), and to function as a porin in vivo when expressed recombin- 
antly in Escherichia coli (Kleivdal et al., 1999). A topology model, suggesting that the FomA protein possesses the general topology of the non-specific porins, has been proposed on the basis of structural principles derived for OMPs of E. coli (Bolstad et al., 1994). This model was largely confirmed by the demonstration of the surface exposure of loops L3 to L7 by epitope insertion mutagenesis (Puntervoll et al., 2000), together with the fact that deletions in loops L1 to L7 did not impede the pore function (Kleivdal et al., 2001). In addition, deletions made in loop L6 led to a marked increase in the uptake of antibiotics through the FomA porin (Kleivdal et al., 2001), suggesting that this loop may function analogously to the pore constriction loop L3 of the structured non-specific porins of E. coli and Rhodobacter capsulatus (Cowan, 1993). Furthermore, a cluster of arginines that contributes to the constriction of the pore has been identified, similar to the cluster observed in the matrix porin $\mathrm{OmpF}$ of E. coli, but positioned closer to the $\mathrm{C}$ terminus (Kleivdal et al., 1999). We recently proposed that these structural deviations from the well-known porins may imply that FomA belongs to a separate subgroup of non-specific porins, reflecting the evolutionary distance between the fusobacteria and the proteobacteria (Kleivdal et al., 2001), but further structural information is clearly needed to establish whether this actually is the case. In the present study, we present the first physicochemical evidence that FomA is a $\beta$-barrel, and examine the role of the proposed loop L1. The results presented here indicate that the proposed loop L1 is located in the periplasm, and that the FomA protein is a 14-stranded $\beta$ barrel.

\section{METHODS}

Bacterial strains and growth conditions. Fusobacterium nucleatum ATCC 10953 was used as a source for wild-type FomA, and was grown anaerobically at $37^{\circ} \mathrm{C}$ in a liquid Bacto-tryptone/yeast extract/ascorbic acid/glucose $/ 0.5 \%$ $\mathrm{NaCl}$ medium (Bolstad et al., 1991).

Escherichia coli strain DH5 $\alpha$ (Hanahan, 1983) was used for cloning purposes. The porin-deficient E. coli K-12 strain CE1224 (Tommassen et al., 1983) was used to express recombinant FomA protein as previously described (Puntervoll et al., 2000). The E. coli strains AK101 and DH5 $\alpha$ mutS were used with the double-primer method for sitedirected mutagenesis (Ohmori, 1994). E. coli was grown aerobically at $37^{\circ} \mathrm{C}$ in LB medium, or, to impose phosphate limitation, in a low-phosphate medium described by Levinthal et al. (1962). For large-scale growth under low-phosphate conditions, E. coli was grown in $200 \mathrm{ml} \mathrm{LB}$ medium overnight; the cells were harvested and washed twice in a low-phosphate medium and used to inoculate a 11 low-phosphate medium culture, which was incubated overnight. The antibiotics chloramphenicol $\left(35 \mu \mathrm{g} \mathrm{ml}^{-1}\right)$, ampicillin $\left(50 \mu \mathrm{g} \mathrm{ml}^{-1}\right)$ and tetracycline $\left(10 \mu \mathrm{g} \mathrm{ml}^{-1}\right)$ were added for selective purposes when necessary.

Plasmids and constructs. The plasmid pHB14 (Jensen et al., 1996) contains the part of the fom $A$ gene encoding the mature part of the protein, immediately downstream of the $p h o E$ promoter and signal sequence encoding part of $p h o E$, and was used to express the FomA protein recombinantly in E. coli in a functional manner (Jensen et al., 1996). Plasmid pHB14E2C was constructed by site-directed mutagenesis using the doubleprimer method (Ohmori, 1994). The pTZ19U $\mathrm{rrn}_{\text {-derived }}$ phagemid $\mathrm{pHKU} \mathrm{rrh}_{\mathrm{r}}$ containing the chimeric phoE/fom $A$ gene from pHB14 and a defective ori region (Kleivdal et al., 1999) was used to produce single-stranded DNA (Sambrook et al., 1989). The E2C (5'-GGTGCAGGCATAACACATGCAGCCTGTACAGATGC-3') and ori repair (5'-GGGAAGCGTGGCGCTTTCTCATAG-3') primers were used, and the sitedirected mutagenesis was performed as described by Kleivdal et al. (1999). The pHB14E2C plasmid sequence was confirmed by using the ABI PRISM BigDye Terminator Cycle Sequencing Ready Reaction Kit and the ABI PRISM 377 DNA Sequencer (Applied Biosystems).

Isolation of FomA from the outer membrane by detergent extraction. The procedure described below was used to isolate FomA protein from the outer membrane of both $F$. nucleatum and E. coli. Bacterial cells from $1 \mathrm{l}$ of the desired culture were harvested in the late exponential phase of growth by centrifugation, washed twice with $100 \mathrm{ml} 50 \mathrm{mM}$ Tris/ $\mathrm{HCl}(\mathrm{pH} 7 \cdot 7)$, resuspended in $25 \mathrm{ml}$ of the same buffer, and disrupted by passage through a French pressure cell three times at 900 p.s.i. $(6 \cdot 2 \mathrm{MPa})$. The samples were collected in pre-cooled tubes, and intact cells were removed by a low-speed centrifugation at $1000 \mathrm{~g}$ for $20 \mathrm{~min}$ at $4{ }^{\circ} \mathrm{C}$. All succeeding centrifugations were performed at $20000 \mathrm{~g}$ for $45 \mathrm{~min}$. The cell envelopes were isolated by centrifugation at $4{ }^{\circ} \mathrm{C}$. The cell envelopes of $F$. nucleatum were resuspended in $20 \mathrm{ml} 2 \%$ Triton $\mathrm{X}-100$, $10 \mathrm{mM} \mathrm{MgCl}$, $10 \mathrm{mM}$ HEPES (pH 7•4), sonicated for $30 \mathrm{~min}$ in a water bath sonicator, incubated for $45 \mathrm{~min}$ at room temperature, and subjected to centrifugation at $4{ }^{\circ} \mathrm{C}$. The cell envelopes of E. coli were resuspended in $20 \mathrm{ml} 0.05 \%$ CHAPS, $50 \mathrm{mM}$ Tris/ $\mathrm{HCl}, 20 \mathrm{mM}$ EDTA ( $\mathrm{pH} 8 \cdot 0$ ), incubated at room temperature for $10 \mathrm{~min}$ on a rotating wheel, and subjected to centrifugation at $14{ }^{\circ} \mathrm{C}$. The supernatant was discarded, and the pellet was resuspended in $10 \mathrm{ml} 1 \%$ octyl $\beta$-glucopyranoside (OBG), $50 \mathrm{mM}$ Tris/ $\mathrm{HCl}, 20 \mathrm{mM}$ EDTA (pH 8.0), and incubated with vigorous shaking (250 r.p.m.) at $37^{\circ} \mathrm{C}$ for $30 \mathrm{~min}$. The residual cell envelope material was pelleted by centrifugation at $24^{\circ} \mathrm{C}$, and the supernatant containing the extracted proteins was collected and stored at $4{ }^{\circ} \mathrm{C}$.

Purification of FomA by chromatography. Anion-exchange chromatography was used as the first step in the purification of FomA. A $20 \mathrm{ml}$ Q-Sepharose column $(1.5 \mathrm{~cm}$ diameter $)$ was equilibrated with $20 \mathrm{mM}$ Tris $/ \mathrm{HCl}$ buffer $(\mathrm{pH} 8 \cdot 0)$, and the flow-through of protein was monitored by measuring $A_{280}$. When the applied sample contained a detergent other than OBG the column was washed with $20 \mathrm{ml} 1 \%$ OBG, $10 \mathrm{mM}$ Tris $/ \mathrm{HCl}(\mathrm{pH} 8 \cdot 0)$ to exchange the detergent. The protein was eluted from the Q-Sepharose column by using a $\mathrm{LiCl}$ gradient. A total volume of $50 \mathrm{ml}$ was used, and the gradient ranged from 0 to $300 \mathrm{mM} \mathrm{LiCl}$ with fixed concentrations of $1 \%$ OBG and $10 \mathrm{mM}$ Tris $/ \mathrm{HCl}(\mathrm{pH} 8 \cdot 0)$. Fractions of $1.5 \mathrm{ml}$ were collected, $A_{280}$ was measured, and fractions of interest were analysed by SDS-PAGE.

Further purification of the FomA protein was achieved by applying size-exclusion chromatography. Fractions enriched in Fom A were pooled, and the volume was reduced to less than $2 \mathrm{ml}$ by using a concentration cell (Amicon) with a cutoff filter of $30 \mathrm{kDa}$. This sample was applied to a Sephacryl 200 column pre-equilibrated with $1 \%$ OBG, $10 \mathrm{mM}$ Tris $/ \mathrm{HCl}$ (pH 8.0), $200 \mathrm{mM} \mathrm{LiCl,} \mathrm{and} \mathrm{size-exclusion} \mathrm{chromatography}$ was conducted in the same buffer at a constant flow of $0.5 \mathrm{ml} \mathrm{min}{ }^{-1}$. Fractions of $1.0 \mathrm{ml}$ were collected, $A_{280}$ was 
measured, and fractions of interest were analysed by SDS-PAGE.

SDS-PAGE and Western blotting. SDS-PAGE was performed as described by Lugtenberg et al. (1975), and the samples were incubated in sample buffer at room temperature or $95^{\circ} \mathrm{C}$ for $5 \mathrm{~min}$ prior to electrophoresis. The SDS-PA gels were either stained with Coomassie brilliant blue R250 (Sigma) or subjected to Western blot analysis as described by Towbin et al. (1979). Anti-FomA antiserum $\phi 239$ (Bakken et al., 1989b) and horseradish-peroxidase-coupled goat anti-rabbit antibody (Bio-Rad) were used as primary and secondary antibodies, respectively, and the immunoblots were developed with 4-chloro-1-naphthol (Bio-Rad).

Analysis of secondary structure content by circular dichroism. Secondary structure content of the FomA protein was evaluated by circular dichroism (CD) spectroscopy using a Jasco J810 spectropolarimeter equipped with a Jasco PTC-423S Peltier element for temperature control. Prior to analysis, the samples were dialysed against a $1 \%$ OBG, $20 \mathrm{mM}$ Tris $/ \mathrm{HCl}$ $(\mathrm{pH} 8.0)$ buffer to reduce the $\mathrm{LiCl}$ concentration to less than $5 \mathrm{mM}$. The CD spectra were recorded at $25^{\circ} \mathrm{C}$ with samples containing $0 \cdot 1-0 \cdot 3 \mathrm{mg}$ protein $\mathrm{ml}^{-1}$ by four consecutive scans at $0.5 \mathrm{~nm}$ wavelength intervals, and the mean spectra were stored. The temperature-dependent stability of secondary structure was monitored by heating the samples at a programmed rate of $1{ }^{\circ} \mathrm{C} \mathrm{min}^{-1}$.

Trypsin treatment of intact cells and cell envelopes containing FomA, and of purified FomA. Trypsin treatment of intact cells and cell envelopes was in essence performed as described by Merck et al. (1997). In short, cells from an overnight culture were pelleted and resuspended in a buffer containing $0 \cdot 1 \mathrm{M}$ Tris $/ \mathrm{HCl}(\mathrm{pH} 8 \cdot 0), 0.25 \mathrm{M}$ sucrose and $10 \mathrm{mM} \mathrm{MgCl}_{2}$, and the samples were incubated on ice for $60 \mathrm{~min}$ with $0 \cdot 1 \mathrm{mg}$ trypsin $\mathrm{ml}^{-1}$. The trypsin reaction was stopped by adding soybean trypsin inhibitor (Sigma) to a final concentration of $500 \mu \mathrm{g} \mathrm{ml}^{-1}$, and the samples were subsequently washed twice with the above-described buffer containing trypsin inhibitor. Cell envelopes to be trypsin treated were isolated by passage through a French pressure cell and subsequent centrifugation as described by Jensen et al. (1996), and subjected to trypsin digestion as described for intact cells. Purified FomA protein was subjected to trypsin digestion by adding trypsin to final concentrations of 10,1 or $0 \cdot 1 \mu \mathrm{g} \mathrm{ml}^{-1}$ and incubating on ice for $60 \mathrm{~min}$; the reaction was stopped as described above. All trypsin-treated samples were immediately analysed by SDS-PAGE and Western blotting to avoid unwanted potential activity of (residual) trypsin.

$\mathrm{N}$-terminal amino acid sequence determination. Samples containing the FomA protein were subjected to SDS-PAGE, and the Coomassie-stained FomA bands were excised. The protein was extracted from the gel by incubation in $70 \%$ formic acid at room temperature overnight (Tsugita et al., 1987), and submitted to the protein sequencing facilities at the University of Oslo for N-terminal sequencing.

Single-channel conductance experiments of FomA reconstituted in lipid bilayer membranes. FomA protein was prepared for single-channel conductance experiments by extracting the protein from OMs with $1 \%$ OBG, followed by SDS-PAGE. Samples were incubated with sample buffer at room temperature prior to SDS-PAGE, and run in parallel in all lanes of a 15-lane SDS-PA gel. The outer lanes were stained with Coomassie blue to guide the excision of non-stained native FomA proteins from the gel, and the protein was eluted with $0.5 \%$ OBG in $20 \mathrm{mM}$ Tris $/ \mathrm{HCl}(\mathrm{pH} 8 \cdot 0)$. The recon- stitution of pore-forming activity in artificial membranes was performed by using black lipid membranes as described previously (Kleivdal et al., 1995).

\section{RESULTS}

\section{Purification of FomA from the cell envelopes of F. nucleatum and $E$. coli}

For structural analysis, the FomA protein was purified to near homogeneity from both cell envelopes of $F$. nucleatum ATCC $10953\left(\right.$ Fom $\left._{10953}\right)$ and the OM of E. coli CE1224 cells expressing FomA (rFomA $\left.{ }_{10953}\right)$. Purification was performed by ion-exchange and sizeexclusion chromatography as described in Methods. In addition, a truncated $37 \mathrm{kDa}$ FomA protein (FomA 10953TRU $)$ was purified in the same manner, after treating OM fractions of F. nucleatum ATCC 10953 with trypsin as described in Methods. N-terminal sequencing yielded mixed signals and demonstrated that the FomA 10953 TRU protein had either D27 or E29 as a new N-terminus, giving a theoretical molecular mass of approximately $37 \mathrm{kDa}$. All the purified FomA proteins were heat-modifiable, since samples prepared at room temperature prior to SDS-PAGE migrated with a higher mobility than boiled samples (Fig. 1). This strongly suggests that the non-boiled purified FomA proteins, including the truncated Fom $A_{10953 T R U}$, migrate as folded monomers in SDS-PAGE. These observations are in line with previous results obtained by our group (Bakken et al., 1989a; Jensen et al., 1996).

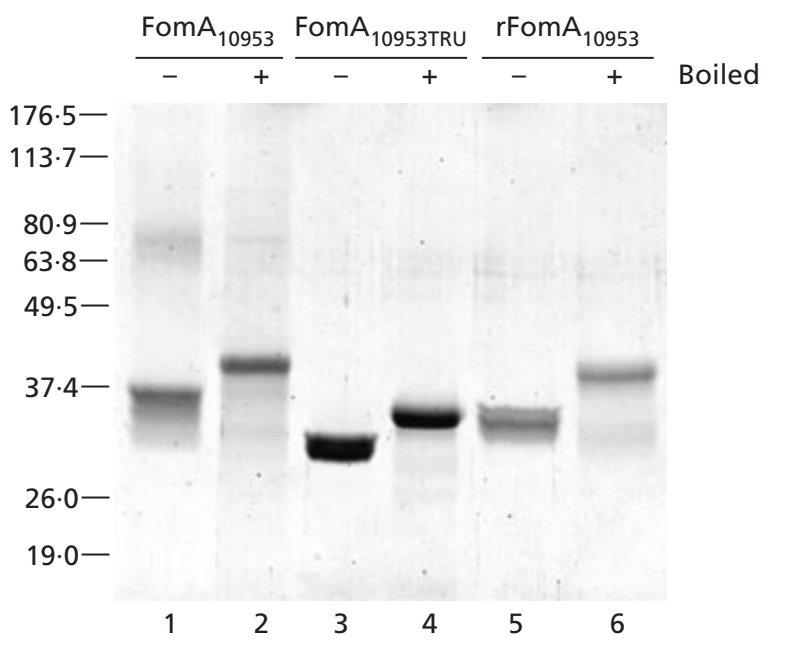

Fig. 1. SDS-PAGE analysis of the purified FomA proteins used in this study. Fom $A_{10953}$, FomA purified from the cell envelope of F. nucleatum ATCC 10953; Fom ${ }_{10953 \mathrm{TRU}}$, a truncated $37 \mathrm{kDa}$ FomA protein purified from trypsin-treated cell envelopes of $F$. nucleatum ATCC 10953. rFomA ${ }_{10953}$, FomA purified from the cell envelope of $E$. coli CE1224. Samples were either boiled for $5 \mathrm{~min}(+)$ or incubated at room temperature $(-)$ prior to SDSPAGE. 


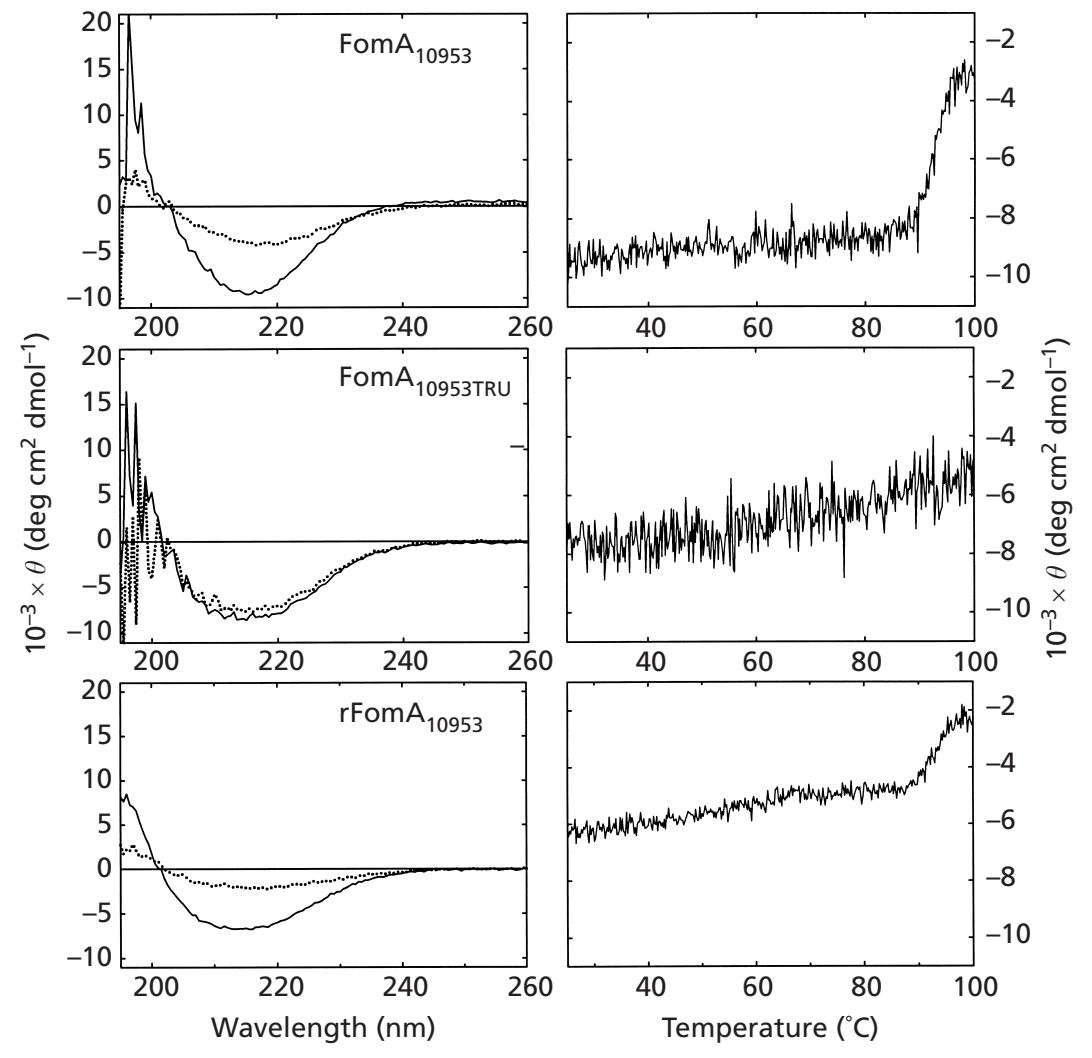

Fig. 2. Evaluation of secondary structure content of the FomA protein by $C D$ analysis. $C D$ analysis of the FomA 10953, FomA $_{10953 \text { TRU }}$ and $\mathrm{rFomA}_{10953}$ proteins was done in a $20 \mathrm{mM}$ Tris/HCl buffer (pH 8.0) containing $1 \%$ OBG. The CD spectra were recorded at $25^{\circ} \mathrm{C}$ (left-hand panels, full lines), and the lowest mean residue ellipticity $(\theta)$ value was determined $(214 \mathrm{~nm})$. Subsequently, thermal denaturation of the protein was monitored by increasing the temperature from $25^{\circ} \mathrm{C}$ to $100{ }^{\circ} \mathrm{C}$ at a rate of $1^{\circ} \mathrm{C} \min ^{-1}$, using $214 \mathrm{~nm}$ as fixed wavelength (right-hand panels). After heating the sample at $100^{\circ} \mathrm{C}$, the temperature was immediately lowered to $25^{\circ} \mathrm{C}$, and another $\mathrm{CD}$ spectrum was recorded (left-hand panels, dotted lines).

\section{Secondary structure content analysis by circular dichroism}

The CD analysis was performed on the Fom $A_{10953}$, FomA $_{10953 \mathrm{TRU}}$ and $\mathrm{rFomA}_{10953}$ proteins, as described in Methods. The CD spectra of the FomA proteins (Fig. 2, left panels), obtained at $25^{\circ} \mathrm{C}$ (full lines), suggest that the FomA protein is composed predominantly of $\beta$ pleated sheet structures, as the topology model suggests. Furthermore, the similarity between the spectra of Fom $A_{10953}$ and Fom $A_{10953 T R U}$ strongly indicates that the truncated Fom $A_{10953 T R U}$ protein possesses essentially the same secondary structure content as the native FomA $_{10953}$ protein. The spectrum obtained with the rFomA $\mathrm{A}_{10953}$ protein differed from the other two spectra (Fig. 2), suggesting that the solubilized $\mathrm{rFomA}_{10953}$ protein has a somewhat different secondary structure content. The FomA proteins were subjected to a thermal denaturation analysis by monitoring at $214 \mathrm{~nm}$ the disruption of secondary structure (Fig. 2, right panels). The thermal melting profiles of FomA $\mathrm{F}_{1053}$ and rFom $A_{10953}$ show cooperative unfolding transitions at $92{ }^{\circ} \mathrm{C}$. However, Fom $A_{10953 T R U}$ does not seem to unfold cooperatively. The rFomA $_{10953}$ protein shows an additional transition step at $68^{\circ} \mathrm{C}$, possibly reflecting two (or more) different conformational populations. CD spectra were also recorded for the samples after heating to $100^{\circ} \mathrm{C}$ and immediate subsequent cooling to $25^{\circ} \mathrm{C}$ (Fig. 2, left panels, dotted lines). The CD spectra of the heat-treated Fom $A_{10953}$ and FFom $_{10953}$ proteins suggest partial refolding but also significant loss of material, possibly due to aggregation. Unlike the FomA $\mathrm{F}_{10953}$ and
rFom $A_{10953}$ proteins, the truncated Fom $A_{10953 \mathrm{TRU}}$ protein does not seem to aggregate upon heating, thus displaying similar secondary structure content after cooling to $25^{\circ} \mathrm{C}$.

\section{Assessment of the topology model of FomA by trypsin treatment of intact cells and cell envelopes, and purified FomA proteins}

The FomA protein has been shown to be highly resistant to trypsin digestion when situated in the outer membrane of both F. nucleatum and E. coli (Bakken et al., 1989a; Jensen et al., 1996), despite having several R and $\mathrm{K}$ residues distributed evenly in the entire primary structure. It was however reported that a small Nterminal segment was cleaved off when intact cells or cell envelopes of F. nucleatum were treated with trypsin, and that E29 became the new N-terminal amino acid, indicating surface exposure of the postulated loop L1 (Bakken et al., 1989a). However, when these experiments were repeated using fresh cells and the conditions described in Methods, the FomA protein appeared to be completely resistant to trypsin (Fig. 3a, lanes 1-4), in the same manner as when present in the OM of intact E. coli cells (Jensen et al., 1996). In contrast, when cell envelopes were treated with trypsin, a small fragment was cleaved off (Fig. 3a, compare lanes 5 and 8), indicating that the residues R26 and R28 were accessible to trypsin and a periplasmic location of these residues. If the N-terminus of the FomA protein was an integral part of the $\beta$-barrel of the FomA protein, as the proposed topology model suggests (Bolstad et al., 1994), one 
(a)

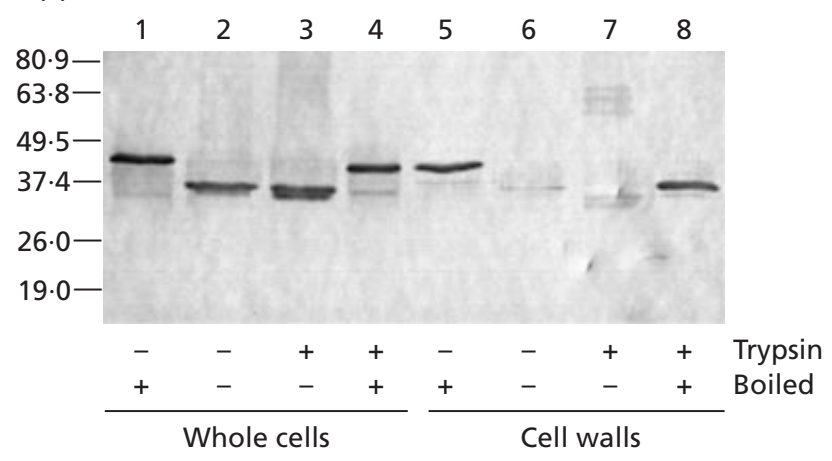

(b)

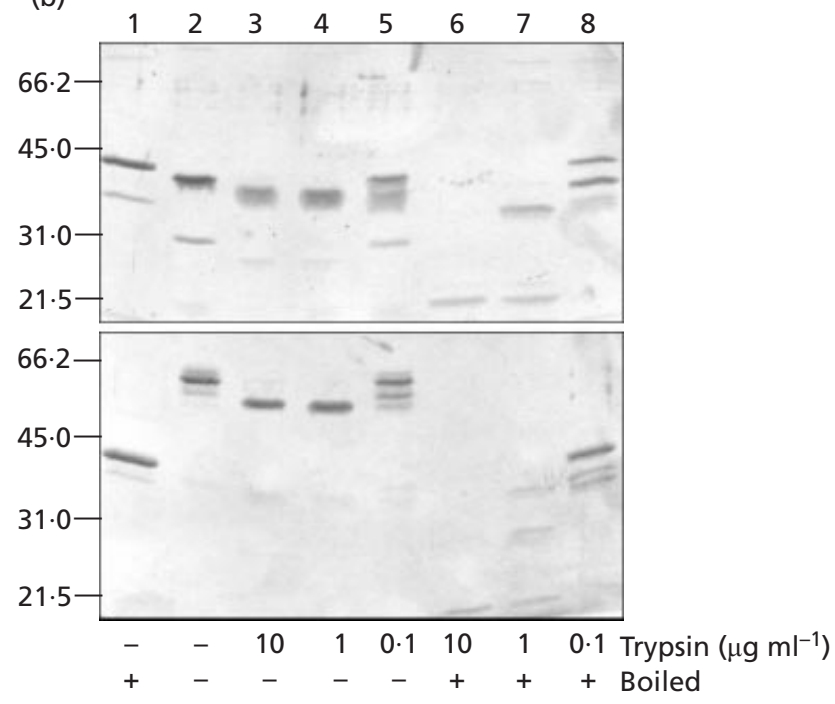

Fig. 3. Trypsin accessibility of FomA protein in intact cells, in cell walls and in solution. (a) Western blot analysis of FomA in whole cells and cell walls. Samples were treated with trypsin as described in Methods where indicated, and either boiled for 5 min $(+)$ or incubated at room temperature $(-)$ prior to SDSPAGE. (b) Western blot analysis of FomA $A_{\text {Fev1 }}$ protein isolated from the OM of $F$. nucleatum Fev1 (lower blot), and rFomA 10953 isolated from the OM of E. coli CE1224 (upper blot), following treatment with trypsin. Three trypsin concentrations were used $\left(0 \cdot 1,1\right.$ and $\left.10 \mu \mathrm{g} \mathrm{ml}^{-1}\right)$, and the experiment was performed as described in Methods. All samples were applied to SDS-PA gels in duplicate: one was boiled $(+)$ in sample buffer, whereas the other was incubated at room temperature $(-)$. Molecular mass standards are given in $\mathrm{kDa}$ to the left.

would expect that at least the $\beta$-strand part of the $\mathrm{N}$ terminus would remain as part of the folded $\beta$-barrel, when migrating as a folded monomer in SDS-PAGE. This does not seem to be the case, since the folded monomer migrates faster after trypsin digestion than the undigested one (Fig. 3a, compare lanes 6 and 7). Furthermore, N-terminal sequencing of the truncated folded monomer FomA 10953TRU $_{\text {isolated by excision }}$ from an SDS-PA gel (corresponding to the one shown in Fig. 1, lane 3), revealed that the original $\mathrm{N}$-terminus was not present, and that the new N-terminus started from either D27 or E29. Since the trimers of the FomA ${ }_{10953}$ protein cannot be observed in SDS-PAGE, we also performed this analysis on the FomA protein from $F$. nucleatum T18 (FomA $\mathrm{T}_{\mathrm{T} 18}$ ) (not shown), which displays stable trimers (apparent molecular mass $\sim 70 \mathrm{kDa}$ ) in SDS-PAGE (Haake \& Wang, 1997). The FomA $\mathrm{T}_{\mathrm{T} 18}$ trimer was not disrupted by the trypsin treatment, since the migration in SDS-PAGE only increased slightly compared to full-length trimers, and the truncated Fom $A_{\text {T18 }}$ protein had new $\mathrm{N}$-termini identical to those observed with Fom $A_{10953 T R U}$.

Several porins are completely resistant to tryptic hydrolysis also when solubilized (Minetti et al., 1998; Rosenbusch, 1974). Since the $37 \mathrm{kDa}$ C-terminal fragment of the FomA protein was completely trypsin resistant when situated in the OM (Bakken et al., 1989a; Jensen et al., 1996), trypsin digestion experiments were applied to the purified FomA proteins to assess the tertiary structure. Since the FomA protein from $F$. nucleatum ATCC 10953 only displays weak trimeric bands on SDS-PAGE (Fig. 1, lane 1), the FomA protein from F. nucleatum Fev1 ( FomA $_{\mathrm{Fev1}}$ ), which has stable trimers in SDS-PAGE (Kleivdal et al., 1995), was purified and included in this analysis. The initial analysis using $10 \mu \mathrm{g}$ trypsin $\mathrm{ml}^{-1}$ revealed extensive digestion, indicating that several trypsin sites, in addition to R26/R28, were susceptible in the FomA proteins in solution. Fig. $3(\mathrm{~b})$ shows a more detailed analysis that was performed with the $\mathrm{rFomA}_{10953}$ and FomA $\mathrm{Fev}_{1}$ proteins. Three different trypsin concentrations were used, $0 \cdot 1,1$ and $10 \mu \mathrm{g} \mathrm{ml}^{-1}$, and the samples were applied to an SDS-PA gel in duplicate; one sample was incubated at room temperature and the other was boiled prior to electrophoresis. It is evident that both populations of OMextracted FomA protein were much more susceptible to trypsin when in solution than when present in the membrane, since the protein is degraded to fragments smaller than the $37 \mathrm{kDa}$ OM-protected fragment (Fig. 3 b, lanes 6-8). Furthermore, the unheated samples show that trypsin digestion apparently leads neither to a dissociation of the trimers of the Fom $\mathrm{A}_{\mathrm{Fev} 1}$ protein, nor to the disintegration of the $\beta$-barrel structure of the folded monomers (Fig. 3b, lanes 3-5). This is in line with the very stable structure revealed by the CD experiments. Finally, trypsin digestion leads to a shift in mobility of both trimers and folded monomer (Fig. 3b, compare lanes 2 and 3), suggesting that the $\mathrm{N}$-terminus is not an integral part of the $\beta$-barrel.

In order to pursue the hypothesis that the $\mathrm{N}$-terminus is not part of the $\beta$-barrel, the $37 \mathrm{kDa}$ truncated FomA $\mathrm{A}_{10953 \mathrm{TR} U}$ was incorporated into artificial bilayer membranes, as described in Methods. Fig. 4 shows that Fom $\mathrm{A}_{10953 \mathrm{TRU}}$ indeed functions as a pore, and a mean single-channel conductance of $1 \cdot 22 \mathrm{nS}$ was found, similar to that observed with full-length FomA ${ }_{10953}(1 \cdot 17 \mathrm{nS})$ (Kleivdal et al., 1995).

\section{Role of the N-terminus of FomA in trimer stability}

The strong sequence conservation of the N-terminus among the different FomA proteins suggests an important structural and/or functional role (Bolstad et al., 


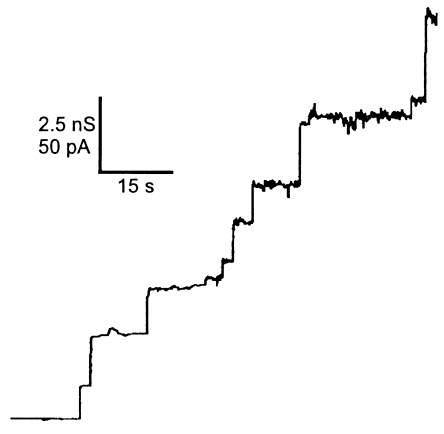

Fig. 4. Analysis of single-channel events due to incorporation of FomA $A_{10953 \text { TRu }}$ into artificial bilayer membranes.

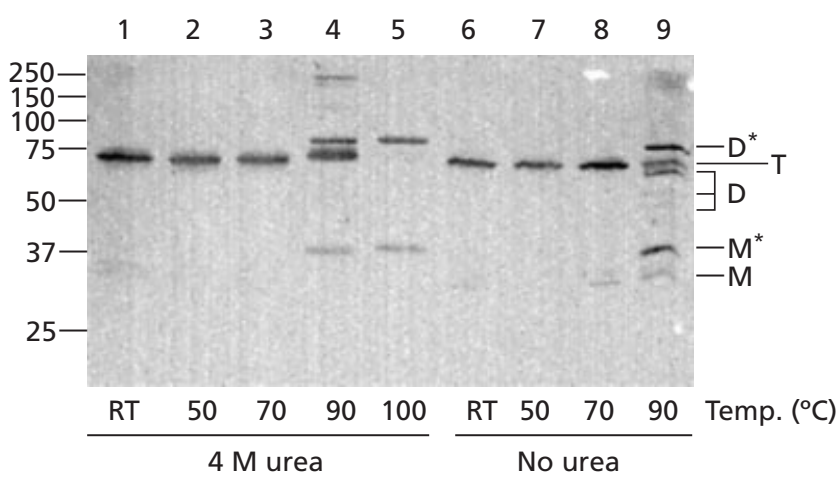

Fig. 5. Western blot analysis of the $\mathrm{rFomA}_{10953 \mathrm{E} 2 \mathrm{C}}$ protein: trimer dissociation and denaturation in vitro. The $\mathrm{rFomA}_{10953 \mathrm{E} 2 \mathrm{C}}$ protein extracted from the OM of $E$. coli CE1224 was incubated at different temperatures in the OBG buffer with and without urea for $20 \mathrm{~min}$, as indicated. The samples were subsequently incubated in a non-reducing sample buffer at room temperature for $5 \mathrm{~min}$ prior to SDS-PAGE. The analysis allowed the observation of intact trimers (T) (lanes 1-4 and 6-9), folded dimers (D) and monomers (M) (lanes 8 and 9), denatured dimers $\left(D^{*}\right)$ and monomers $\left(\mathrm{M}^{*}\right)$ (lanes 4,5 and 9 ). Molecular mass standards are given in KDa to the left.

1994). In a parallel work, an $\mathrm{rFomA}_{10953}$ mutant carrying an E2C substitution was constructed (named $\left.\mathrm{rFomA}_{10953 \mathrm{E} 2 \mathrm{C}}\right)$, in an attempt to identify the trimeric interface of the FomA protein (L. J. Bruseth, unpublished). This E2C modification was found to have a trimer-stabilizing effect when the protein was recombinantly expressed in E. coli, leading to trimers in a nonreducing SDS-PAGE analysis (Fig. 5, e.g. lane 1), unlike the rFomA $A_{10953}$ protein (e.g. Fig. 1, lane 5). The observed trimer-stabilizing effect is the result of the cysteine of one monomer of the $\mathrm{rFomA}_{10953 \mathrm{E} 2 \mathrm{C}}$ protein forming a disulphide bond with the cysteine of one of the neighbouring monomers within the trimer, since no trimers were visible after reduction of the disulphide bond (not shown). This disulphide bond apparently stabilizes the entire trimeric structure, implying the direct involvement of the $\mathrm{N}$-terminus in trimer stability. In order to analyse this $\mathrm{E} 2 \mathrm{C}$ mutant more closely, the
$\mathrm{rFomA}_{10953 \mathrm{E} 2 \mathrm{C}}$ protein was isolated from the OM of $E$. coli CE1224 cells as described in Methods, and solubilized $\mathrm{rFomA}_{10953 \mathrm{E} 2 \mathrm{C}}$ was subjected to a denaturation analysis (Fig. 5). This analysis shows that the $\mathrm{rFomA}_{10953 \mathrm{E} 2 \mathrm{C}}$ protein is highly resistant to denaturation by temperature, and that, in the absence of a reducing agent, the protein denatures into a monomer and a covalently linked dimer, when heated at $100{ }^{\circ} \mathrm{C}$ for 20 min prior to SDS-PAGE. The effects of exposure to various temperatures were followed both in $0.5 \%$ OBG, $10 \mathrm{mM}$ Tris/HCl (pH 8.0) solution (Fig. 5, lanes 6-9) and in the same solution also containing $4 \mathrm{M}$ urea (Fig. 5 , lanes $1-5)$. The results clearly show that when the $\mathrm{rFomA}_{10953 \mathrm{E} 2 \mathrm{C}}$ protein was heated to $90^{\circ} \mathrm{C}$ in the presence of urea, a portion of the protein denatured completely into the $40 \mathrm{kDa}$ monomer and the $80 \mathrm{kDa}$ dimer. But, in the absence of urea, several additional protein bands can be observed on the SDS-PA gel, including bands corresponding to folded monomers $(38 \mathrm{kDa})$ and folded dimers $(54 \mathrm{kDa}, 62 \mathrm{kDa})$. This demonstrates that the trimers of the FomA protein can disintegrate into folded monomers (and in the case of the E2C mutant, folded dimers), and that the monomers and dimers are less stable than the intact trimer in vitro (Fig. 5, compare lanes 4 and 9).

\section{DISCUSSION}

The CD spectra strongly suggest that the FomA protein is rich in $\beta$-sheet structure and are similar to those obtained with other porins from E. coli (Rosenbusch, 1974) and from Neisseria meningitidis (Minetti et al., 1997, 1998). Furthermore, the thermal melting profiles suggest that the FomA protein possesses a $\beta$-barrel architecture typical for OMPs (Schulz, 2000), since the cooperative unfolding transition occurs at high temperatures $\left(>80^{\circ} \mathrm{C}\right)$, reflecting the very stable three-dimensional structures of these proteins. The evidence for a $\beta$ barrel architecture is in line with the published topology model for the FomA protein suggesting that the FomA protein is a 16-stranded $\beta$-barrel (Bolstad et al., 1994, 1995). The apparent lower content of secondary structure observed with the $\mathrm{rFomA}_{10953}$ protein in combination with its melting profile suggests that at least a fraction of this protein has a different conformation in solution than the Fom $\mathrm{A}_{10953}$ protein. This may indicate either that a population of the $\mathrm{rFomA}_{10953}$ protein expressed in E. coli CE1224 does not attain the native conformation, or that a change in conformation is induced as a consequence of the detergent extraction. Since the $\mathrm{rFomA}_{10953}$ protein in the OM possesses other characteristics indicating proper folding, such as heat modifiability and trypsin resistance, and the isolated protein has a mean single-channel conductance very similar to that of the FomA $A_{10953}$ protein (Jensen et al., 1996), the latter explanation is favoured. Trypsin analysis of the purified FomA proteins strongly suggests that both the quaternary and tertiary structures are intact in solution, in spite of increased sensitivity to trypsin compared to the FomA proteins present in the $\mathrm{OM}$, since neither folded monomers nor trimers are 
(completely) disrupted by proteolysis (Fig. 3b, lanes $3-5)$.

The trypsin analysis of the FomA protein present in the $\mathrm{OM}$ and in solution also provided new structural information. In contrast to earlier published work (Bakken et al., 1989a), no $\mathrm{R}$ or $\mathrm{K}$ residues seem to be accessible to trypsin on the surface of intact cells. Instead, the results presented here suggest that the trypsin site reported to be exposed on the cell surface is in fact exposed to the periplasm, since it is fully accessible to trypsin only when cell envelopes are treated with trypsin. Thus residues 1-28 do not seem to be part of the $\beta$-barrel, since the $\mathrm{N}$-terminal fragment containing these residues apparently dissociates from the rest of the protein, as evident from the increased mobility in SDSPAGE and the fact that none of these residues can be found by $\mathrm{N}$-terminal sequencing. Furthermore, the first putative membrane-spanning segment of the topology model of the FomA protein contains several alternating proline residues, and hence this segment cannot exist as a classical $\beta$-strand (Bolstad et al., 1994). The 28 aa Nterminal fragment also seems to dissociate from the FomA protein when subjected to trypsin treatment in solution, since there is a shift in the mobility of both the folded trimers of Fom $\mathrm{A}_{\mathrm{Fev} 1}$ and the folded monomers of rFomA $_{10953}$ in SDS-PAGE (Fig. 3b, compare lanes 2 and 4). Finally, the fact that several additional trypsin sites were cleaved in solubilized FomA protein (Fig. 3b, lanes 6 and 7), with no apparent effect on the migration of the folded barrel (Fig. 3b, lanes 3 and 4), together with the fact that Fom $A_{10953 T R U}$ functions as a pore (Fig. 4) with properties similar to those of the Fom $\mathrm{A}_{10953}$ protein, strongly supports the hypothesis that the $\mathrm{N}$-terminus is not part of the $\beta$-barrel.

Earlier work has demonstrated that it is possible to replace residues 8 to 23 with the residues RS without the loss of pore function (Kleivdal et al., 2001), suggesting that this segment is not critical for maintaining the $\beta$ barrel structure of the FomA protein. In support of this is also the fact that the $37 \mathrm{kDa}$ trypsin fragment of the FomA (FomA $\left.A_{10953 T R U}\right)$ protein functioned as an intact pore in artificial bilayer membranes (Fig. 4), with a mean single-channel conductance similar to that of the fulllength Fom $\mathrm{A}_{10953}$ protein. On the other hand, the results obtained with the E2C FomA mutant protein suggest that the $\mathrm{N}$-terminus plays a role in stabilizing the quaternary structure, since the $\mathrm{rFomA}_{10953 \mathrm{E} 2 \mathrm{C}}$ protein displays more stable trimers than the wild-type FomA $A_{10953}$ protein under non-reducing conditions, due to a disulphide bond between two monomers within the trimer.

In the light of the results presented here, we propose an alternative topology model where the C-terminal part of the protein forms a 14-stranded $\beta$-barrel (Fig. 6). Although the results do not directly implicate the second putative $\beta$-strand of the original model, the constriction rules for transmembrane $\beta$-barrels formulated by Schultz (2000) imply an even number of $\beta$-strands, thus leading us to propose that the first two strands and loop L1 of

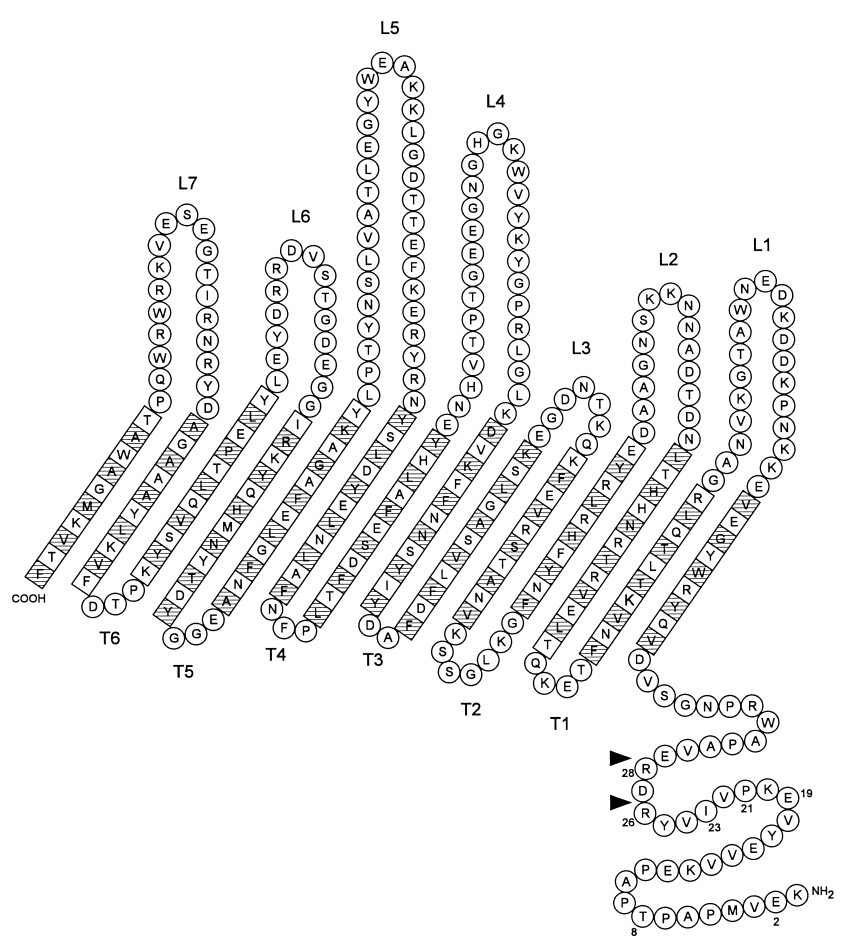

Fig. 6. The 14-stranded topology model of the FomA protein of $F$. nucleatum ATCC 10953. The top of the model shows the putative surface-exposed loops and the central part represents the presumed transmembrane segments. Amino acid residues, shown in one-letter code, are indicated by boxes when they are supposed to form $\beta$-strands (shaded box if proposed to face the lipids or the subunit interface) and circles for turns (T), loops (L) and the putative periplasmic $\mathrm{N}$-terminal domain. Amino acid residues referred to in the text are numbered, and the arrows indicate the sites that were accessible to trypsin when cell envelopes containing FomA were treated. The GenBank accession number for the Fom $A_{10953}$ sequence is $X 72583$.

the original model are located in the periplasm. The 14stranded $\beta$-barrel topology model not only conforms to the results presented here, but is also in accordance with previously published results for the FomA porin (Kleivdal et al., 1999, 2001; Puntervoll et al., 2000). The insertion of a foreign epitope after E19 did not result in the surface exposure of this epitope, in contrast to similar insertions in loops L2 to L6 (named according to the current topology model - Fig. 6) (Puntervoll et al., 2000), in line with a periplasmic location of this part of the protein. Furthermore, neither the insertion of a foreign epitope after E19 (Puntervoll et al., 2000), nor the deletion of residues 8-23 (Kleivdal et al., 2001), severely affected the function of the FomA porin, in line with the $\mathrm{N}$-terminal part not being an integral part of the $\beta$-barrel. Recently, the projection structure of the $E$. coli OmpG porin was published at $6 \AA(0 \cdot 6 \mathrm{~nm})$ resolution (Behlau et al., 2001), and it was suggested that this porin is a 14 -stranded $\beta$-barrel. Compared to the classical non-specific proteobacterial porins, the OmpG porin is also atypical in that it does not seem to form trimers, in contrast to the FomA porin (Kleivdal et al., 
1995). In conclusion, the FomA porin, along with the OmpG porin from E. coli, seems to deviate from the common understanding that non-specific porins are 16stranded $\beta$-barrels. In order to assess the accuracy of this novel 14-stranded topology model, obtaining the crystal structure of FomA would be of utmost value, and this is our current goal. The purification procedures presented here form a solid base for obtaining large amounts of pure protein for crystallization.

\section{ACKNOWLEDGEMENTS}

This work was supported by the Norwegian Research Council. We are grateful to M. Thorolfsson and $\operatorname{Dr} \mathrm{A}$. Martinez, University of Bergen, and Dr H. H. Hauge, University of Oslo, for competent assistance with the circular dichroism experiments. We also appreciate the assistance from Dr V. Bakken, University of Bergen, in cultivating the $F$. nucleatum T18 cells. Finally, we acknowledge Nina Glomnes for excellent technical assistance.

\section{REFERENCES}

Bakken, V., Aaro, S. \& Jensen, H. B. (1989a). Purification and partial characterization of a major outer-membrane protein of Fusobacterium nucleatum. J Gen Microbiol 135, 3253-3262.

Bakken, V., Aaro, S., Hofstad, T. \& Vasstrand, E. N. (1989b). Outer membrane proteins as major antigens of Fusobacterium nucleatum. FEMS Microbiol Immunol 1, 473-483.

Behlau, M., Mills, D. J., Quader, H., Kuhlbrandt, W. \& Vonck, J. (2001). Projection structure of the monomeric porin OmpG at $6 \AA$ resolution. J Mol Biol 305, 71-77.

Bolstad, A. I., Skaug, N. \& Jensen, H. B. (1991). Use of synthetic oligonucleotide DNA probes for the identification of different strains of Fusobacterium nucleatum. J Periodontal Res 26, 519-526.

Bolstad, A. I., Tommassen, J. \& Jensen, H. B. (1994). Sequence variability of the $40-\mathrm{kDa}$ outer membrane proteins of Fusobacterium nucleatum strains and a model for the topology of the proteins. Mol Gen Genet 244, 104-110.

Bolstad, A. I., Høgh, B. T. \& Jensen, H. B. (1995). Molecular characterization of a 40-kDa outer membrane protein, FomA, of Fusobacterium periodonticum and comparison with Fusobacterium nucleatum. Oral Microbiol Immunol 10, 257-264.

Bolstad, A. I., Jensen, H. B. \& Bakken, V. (1996). Taxonomy, biology, and periodontal aspects of Fusobacterium nucleatum. Clin Microbiol Rev 9, 55-71.

Cowan, S. W. (1993). Bacterial porins: lessons from three highresolution structures. Curr Opin Struct Biol 3, 501-507.

Cowan, S. W., Schirmer, T., Rummel, G., Steiert, M., Ghosh, R., Pauptit, R. A., Jansonius, J. N. \& Rosenbusch, J. P. (1992). Crystal structures explain functional properties of two E. coli porins. Nature 358, 727-733.

Dutzler, R., Rummel, G., Alberti, S., Hernandez-Alles, S., Phale, P., Rosenbusch, J., Benedi, V. \& Schirmer, T. (1999). Crystal structure and functional characterization of OmpK36, the osmoporin of Klebsiella pneumoniae. Struct Fold Des 7, 425-434.

Haake, S. K. \& Wang, X. (1997). Cloning and expression of FomA, the major outer-membrane protein gene from Fusobacterium nucleatum T18. Arch Oral Biol 42, 19-24.

Hanahan, D. (1983). Studies on transformation of Escherichia coli with plasmids. J Mol Biol 166, 557-580.
Heller, K. B. (1978). Apparent molecular weights of a heatmodifiable protein from the outer membrane of Escherichia coli in gels with different acrylamide concentrations. J Bacteriol 134, 1181-1183.

Hirsch, A., Breed, J., Saxena, K., Richter, O. M., Ludwig, B., Diederichs, K. \& Welte, W. (1997). The structure of porin from Paracoccus denitrificans at $3 \cdot 1 \AA$ resolution. FEBS Lett 404, 208-210.

Jensen, H. B., Skeidsvoll, J., Fjellbirkeland, A., Høgh, B., Puntervoll, P., Kleivdal, H. \& Tommassen, J. (1996). Cloning of the fomA gene, encoding the major outer membrane porin of Fusobacterium nucleatum ATCC10953. Microb Pathog 21, 331342.

Kleivdal, H., Benz, R. \& Jensen, H. B. (1995). The Fusobacterium nucleatum major outer-membrane protein (FomA) forms trimeric, water-filled channels in lipid bilayer membranes. Eur J Biochem 233, 310-316.

Kleivdal, H., Benz, R., Tommassen, J. \& Jensen, H. B. (1999). Identification of positively charged residues of FomA porin of Fusobacterium nucleatum which are important for pore function. Eur J Biochem 260, 818-824.

Kleivdal, H., Puntervoll, P. \& Jensen, H. B. (2001). Topological investigations of the FomA porin from Fusobacterium nucleatum and identification of the constriction loop L6. Microbiology 147, 1059-1067.

Koebnik, R., Locher, K. P. \& Van Gelder, P. (2000). Structure and function of bacterial outer membrane proteins: barrels in a nutshell. Mol Microbiol 37, 239-253.

Kreusch, A. \& Schulz, G. E. (1994). Refined structure of the porin from Rhodopseudomonas blastica. Comparison with the porin from Rhodobacter capsulatus. J Mol Biol 243, 891-905.

Levinthal, C., Signer, E. R. \& Fetherolf, K. (1962). Reactivation and hybridization of reduced alkaline phosphatase. Proc Natl Acad Sci U S A 48, 1230-1237.

Lugtenberg, B., Meijers, J., Peters, R., van der Hoek, P. \& van Alphen, L. (1975). Electrophoretic resolution of the "major outer membrane protein" of Escherichia coli K12 into four bands. FEBS Lett 58, 254-258.

Merck, K. B., de Cock, H., Verheij, H. M. \& Tommassen, J. (1997). Topology of the outer membrane phospholipase A of Salmonella typhimurium. J Bacteriol 179, 3443-3450.

Minetti, C., Tai, J. Y., Blake, M. S., Pullen, J. K., Liang, S. M. \& Remeta, D. P. (1997). Structural and functional characterization of a recombinant PorB class 2 protein from Neisseria meningitidis. Conformational stability and porin activity. J Biol Chem 272, 10710-10720.

Minetti, C. A., Blake, M. S. \& Remeta, D. P. (1998). Characterization of the structure, function, and conformational stability of PorB class 3 protein from Neisseria meningitidis. A porin with unusual physicochemical properties. J Biol Chem 273, 2532925338.

Moore, W. E. \& Moore, L. V. (1994). The bacteria of periodontal diseases. Periodontol 2000 5, 66-77.

Nakae, T. (1976). Outer membrane of Salmonella. Isolation of protein complex that produces transmembrane channels. J Biol Chem 251, 2176-2178.

Ohmori, H. (1994). A new method for strand discrimination in sequence-directed mutagenesis. Nucleic Acids Res 22, 884-885.

Puntervoll, P., Kleivdal, H., Dahl, K. O., Bitter, W., Tommassen, J. \& Jensen, H. B. (2000). The Fusobacterium nucleatum porin FomA possesses the general topology of the non-specific porins. Microbiology 146, 1437-1445. 
Rosenbusch, J. P. (1974). Characterization of the major envelope protein from Escherichia coli. J Biol Chem 248, 8019-8029.

Sambrook, J., Fritsch, E. F. \& Maniatis, T. (1989). Molecular Cloning: a Laboratory Manual, 2nd edn. Cold Spring Harbor, NY : Cold Spring Harbor Laboratory.

Schulz, G. E. (2000). Beta-barrel membrane proteins. Curr Opin Struct Biol 10, 443-447.

Tommassen, J., van Tol, H. \& Lugtenberg, B. (1983). The ultimate localization of an outer membrane protein of Escherichia coli K12 is not determined by the signal sequence. EMBO $J \mathbf{2}$, $1275-1279$.

Towbin, H., Staehelin, T. \& Gordon, J. (1979). Electrophoretic transfer of proteins from polyacrylamide gels to nitrocellulose sheets: procedure and some applications. Proc Natl Acad Sci US A 76, 4350-4354.

Tsugita, A., Ataka, T. \& Uchida, T. (1987). Approaches for submicrosequencing. J Protein Chem 6, 121-130.

Weiss, M. S. \& Schulz, G. E. (1992). Structure of porin refined at 1.8 A resolution. J Mol Biol 227, 493-509.

Zeth, K., Diederichs, K., Welte, W. \& Engelhardt, H. (2000). Crystal structure of Omp32, the anion-selective porin from Comamonas acidovorans, in complex with a periplasmic peptide at 2.1 A resolution. Structure Fold Des 8, 981-992.

Received 16 July 2002; accepted 18 July 2002. 